\begin{tabular}{|l|l|l||}
\hline \multicolumn{2}{|c|}{ PublisherInfo } \\
\hline \hline PublisherName & $:$ & BioMed Central \\
\hline \hline PublisherLocation & $:$ & London \\
\hline \hline PublisherImprintName & $:$ & BioMed Central \\
\hline \hline
\end{tabular}

\title{
Mutations in the WISP3gene cause PPD
}

\begin{tabular}{||l|l|l||}
\hline \multicolumn{2}{|c||}{ ArticleInfo } \\
\hline \hline ArticleID & $:$ & 235 \\
\hline \hline ArticleDOI & $:$ & $10.1186 /$ ar-1999-66738 \\
\hline \hline ArticleCitationID & $:$ & 66738 \\
\hline \hline ArticleSequenceNumber & $:$ & 192 \\
\hline \hline ArticleCategory & $:$ & Paper Report \\
\hline \hline ArticleFirstPage & $:$ & 1 \\
\hline \hline ArticleLastPage & $:$ & 3 \\
\hline \hline & & RegistrationDate : 1999-10-26 \\
ArticleHistory & $:$ & OnlineDate $\quad$ 1999-10-26 \\
\hline \hline ArticleCopyright & $:$ & Current Science Ltd1999 \\
\hline \hline ArticleGrants & $:$ & \\
\hline \hline ArticleContext & $:$ & 130753311 \\
\hline \hline
\end{tabular}


Ali Hajeer, Aff1

Aff1 Manchester University Medical School, UK

\section{Keywords}

Cartilage, genetics, mutation, PPD, WISP3

\section{Context}

Progressive pseudorheumatoid dysplasia (PPD;MIM208230b) is an autosomal-recessive disorder that is clinically characterised by spondyloepiphyseal dysplasia and progressive arthropathy and has clinical similarities to rheumatoid arthritis. However, PPD is characterised by normal sedimentation rate, negative rheumatoid factor and normal histological synovial tissues. Genetic linkage analysis located the position of a candidate gene for PPD to chromosome 6q in a 3-cM interval between D6S1594 and D6S432 microsatellite markers. To identify and characterise the gene(s) for PPD in the area of linkage on chromosome 6q22, and to investigate the candidate gene for mutations in patients from different ethnic backgrounds.

\section{Significant findings}

WISP3 was identified as the gene responsible for PPD in nine of 13 families. Nine different WISP3 functional mutations were identified in patients but not in any of 100 control alleles. The mutations were homozygous in consanguineous families, while all non-consanguineous families were compound heterozygous. WISP 3 mutations were identified in nine of the 13 families. A list of allelic variants of WISP3 is available (OMIM).

WISP3 transcripts were not detected in different tissues using Northern blotting. RT-PCR, however, was able to detect the message for WISP3in human synoviocytes, articular cartilage chondrocytes, and bone-marrow-derived mesenchymal progenitor cells, but not in lymphoblasts or fibroblasts.

\section{Comments}


The authors have identified, for the first time, the gene causing PPD as being WISP3. Several polymorphisms were identified which seem to encode the same phenotype in several families from different ethnic backgrounds, but in four families, no coding region polymorphisms were detected. Polymorphisms within the 5? and 3? ends of the gene may influence the level of the protein and it may be useful to investigate this further in families showing such polymorphisms. However, the relatively low levels of mRNA and the limited tissue distribution of expression make this a difficult task. This article sheds new light on the genetics of PPD and opens up new doors for future genetic testing and gene therapy for PPD.

\section{Methods}

A total of 13 families, from different ethnic backgrounds, affected by PPD were recruited for this study. Of the 13, six families were consanguineous and seven were non-consanguineous. All patients were of childhood age at onset and presented with enlargement of proximal interphalangeal joints and progressive stiffness and contractures of other joints. Linkage analysis narrowed the area to $2 \mathrm{cM}$, between marker D6S1594 and D6S1706, and the fully linked marker (D6S416) was contained in the pre-sequenced PAC dJ142L7. Analysis of the PAC sequence using RepeatMasker and BLAST softwares identified two potential candidates: LAMA4 and WISP3. WISP3 (MIM603400) is a member of the CCN (CTGF, cyr ${ }^{61} / \mathrm{cef}^{10}$,nov) gene family, which encode cysteine-rich secreted proteins with roles in cell growth and differentiation.

Identification of different WISP3 mutations was carried out by direct sequencing. Expression of WISP3in different tissues was assessed by reverse transcriptase polymerase chain reaction (RT-PCR) and Northern blotting.

\section{References}

1. Hurvitz JR, Suwairi WM, Van Hul W, El-Shanti H, Superti-Furga A, Roudier J, Holderbaum D, Pauli RM, Herd JK, Van Hul EV, Rezai-Delui H, Legius E, Le Merrer M, Al-Alami J, Bahabri SA, Warman ML: Mutations in the CCN gene family member WISP3cause progressive pseudorheumatoid dysplasia. Nat Genet. 1999, 23: 94-98.

This PDF file was created after publication. 